Available Online : https://proceeding.researchsynergypress.com/index.php/cset/index

RSF Conference Series: Engineering and Technology

ISSN 2809-6843 (Online) | 2809-6878 (Print)

Volume 1 Number 1 (2021): 661-668

\title{
Bioplastic Production from Eucheuma Cottoni
}

\author{
Mahreni' $^{1}$ Yuli Ristianingsih"1, Asep Saefudin², Affifuroyan Aflah Akmal', Annisa Hindun \\ Narullita ${ }^{3}$ \\ ${ }^{1}$ Chemical Engineering, Faculty of Industrial Engineering, UPN "Veteran" Yogyakarta \\ 2 Department of International Relations, Faculty of Social and Political Science, UPN “Veteran" Yogyakarta \\ ${ }^{3}$ Staff at Private Institutions
}

\begin{abstract}
Plastic waste has become a global problem because it causes environmental pollution. This is because plastic waste is difficult to decompose. There have been numerous solutions proposed, one of which is the use of bioplastics. In this research, the bioplastics were made from thirdgeneration biomass, namely the eucheuma cottoni. Eucheuma cottoni is contains biopolymer carrageenan, a carbohydrate with unit structures consisting of d-galactose and 3,6 anhydro galactose with glycosidic bonds. Goal this research is study the effects of sorbitol plasticizer content and bioplastics manufacturing temperature on bioplastics, tensile strength, elongation, and biodegradation rate. The bioplastics were made by extracting 10 grams of eucheuma cottoni powder in $200 \mathrm{ml}$ of distilled water. The algae extract was added with sorbitol (plasticizer) and heated at various temperatures from $45^{\circ} \mathrm{C}$ until $60^{\circ} \mathrm{C}$. The mixture was poured into a mold tin and dried in the oven to a constant weight. The resulting bioplastics were then characterized to determine the tensile strength and biodegradation rate. The results showed that increasing the plasticizer content from 3.5\% reduced the tensile strength, however, it increased the elongation and biodegradation rate. The optimal plasticizer content was $4 \%$ with a tensile strength value of $4.8309 \mathrm{Mpa}$, elongation of $24.1548 \%$, and biodegradation rate of $26.9392 \%$. The temperature variable showed that increasing the temperature of making bioplastics could reduce tensile strength, increase elongation and biodegradation rate of bioplastics. The optimum temperature for making bioplastics at $45^{\circ} \mathrm{C}$ obtained a tensile strength of $6.28 \mathrm{Mpa}$ and an elongation of $20.67 \%$. The biodegradation rate was $39.6665 \%$, and the best sorbitol content was received at $4 \%$.
\end{abstract}

Keywords: Biodegradable, Bioplastic, Carrageenan, Sorbitol

This is an open access article under the CC-BY-NC license

\section{INTRODUCTION}

The world's level of plastic production has increased from 245 million metric tons to about 359 million metric tons in 2018, and is expected to triple by 2050 (Chia et., al., 2020). Plastic is one of the items that can not be separated for human life. Besides being used as packaging material, plastic is also used in household appliances such as jars, plates, glasses, etc. The high rate of plastic production is not matched by the relatively low rate of plastic recycling. Most of the plastic is disposed of in landfills. However, the decomposition of plastic is the most difficult among all common commodities such as fruits, paper, leather and aluminum. This is because it may survive in nature for centuries before decaying (Chen and Yan, 2020). This "white pollution" caused by tremendous plastic debris has also occurred in the aquatic environments, causing serious impacts on marine life such as ocean animals and coral reefs. For instance, these marine debris has caused problems such as ingestion, entanglement, debilitation and suffocation to the marine species, leading to reduced life quality, drowning, limited capabilities to avoid predator, lower reproductive capacity, impairment of feeding ability and death. There are also increasing concerns on the potential effects of microplastics on human health since microplastics have been detected in food and air samples (Stephanis et., al., 2013). Disposal of plastic waste which are major cause of environment pollution becomes carcinogenic to human, birth defects, impaired immunity, endocrine disruption, development and reproductive effect.

One of the efforts to reduce the problem of plastic waste by making plastic that can degraded otherwise known as biodegradable plastic. Biodegradable plastic or bioplastic is plastic that can be used like conventional plastic, however will be easily decomposed by activity microorganisms after use and discharged into the environment. Bioplastic made of renewable materials, that is, from the compounds present in plants such as starch, cellulose, collagen, casein, protein or lipid found in animals (Sanjaya et., al.,2013). 
The third generation of raw materials for bioplastics comes from marine biomass such as macroalgae (Syed Ali Ashter, 2016). Macroalgae are abundantly available in Indonesia and grow regardless of seasons to guarantee the continuity of biomass availability. The advantage of using algae is that the regeneration period is faster than land plants and does not require cultivation (Aparicio et., al., 2021). Besides that, the carbohydrate content of algae, mainly blonde algae, namely carrageenan, reaches 61\% (Daniel et., al., 2021).So that blonde algae is a potential bioplastic raw material. The contribution of biodegradable plastics is still minimal, less than $1 \%$ of the total use of plastics, and the use of bioplastics continues to grow widely, so it isessential to research bioplastics from non-food and sustainable materials (Syed Ali Ashter, 2016). The molecular structure of carrageenan can be seen in Figure 1. as follows:
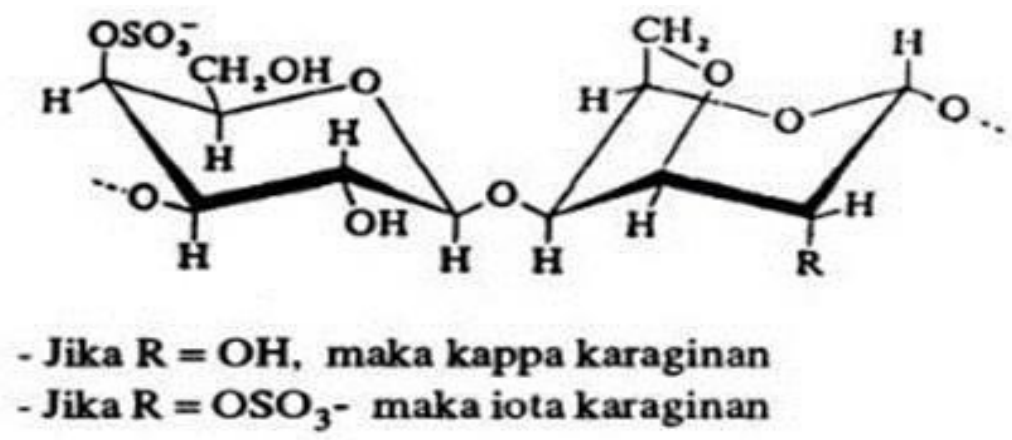

Figure 1. Molecular structure of carrageenan d-galactose and 3,6 anhydrogalactose units with glycosidicbonds If $R=O H$, then kappa karaginan $=>$ If $\mathrm{R}=\mathrm{OF}$, then the carrageenan kappa If $\mathrm{R}=\mathrm{OSO}_{3^{-}}$, maka iota karaginan $=>$If $\mathrm{R}=\mathrm{OSO}_{3^{-}}$, then carrageenan iota

\section{LITERATURE REVIEW}

Biodegradable plastics or bioplastics are plastics derived from renewable biomass resources such as wheat, cassava, etc. (Averoes et. Al., 2012). Bioplastics are substitutes for conventional petroleumbased plastics in recent decades. Bioplastics have been used and developed for the last 25 years due to various problems caused by the use of petroleum-based plastics. Averoes et. al., 2012; Sugih, 2008). Not only corn and soybeans, other food crops such as cassava, wheat, potatoes, sago, etc. are used as raw materials for making bioplastics to replace the use of petroleum-based plastics including improving the quality of life around the world (Barker et. Al., 2009; Ahmad et al., 2009). Al., 2012). The crops are a food resources for humans so it is not appropriate to convert crops into plastic. This would disrupt human food supplies, creating additional pressure on the world's dwindling food resources. To maintain normally consumption of the crops as raw materials for plastics producing, development of alternative sustainable raw materials has been one of strategies and plans to ensure the world's food security. In recent years, a number of researchers have looked to get plastics from marine algae as an alternative raw material. Due to their rapid growing, up to $20 \%$ per day (Machmud et. Al., 2013), easy cultivation and the incredible area of the sea, development of raw material from marine algae can ensure a sustainable raw material for producing plastics.

Carrageenans have a structure similar to land plant carbohydrates, but at the number $4 \mathrm{C}$ atom of each repeating dimer, it is binds a sulfate group. The second characteristic is a bond between the number $6 \mathrm{C}$ atomand the number $3 \mathrm{C}$ atom in each dimer, which repeats the bond and forms a closed structure of anhydro galactose. The hydroxyl group bonded by the $C$ atom number 2,4 is an active group that can be used as a reactive group to form carrageenan derivative compounds. Pure carrageenan cannot be plastic and requires a plasticizer. Plasticizer material is a poly-functional compound; for example, polyol (Sorbitol) can be used as a plasticizer because it can form cross-links with carrageenan molecules resulting in flexible properties and reducing the level of the brittleness of the resulting film (Chia et al., 2020). The affinity of the two components influences the interaction between the polymer and the plasticizer; if the affinity of the plasticizer polymer is not strong, there will be plasticization between structures (plasticizer molecules are only distributed between 
structures). This plasticization only affects the movement and mobility of the structure. If the polymer-polymer interaction is strong enough, the plasticizer molecules will diffuse into the polymer chain. The ratio of carrageenan and plasticizer is a process parameter that directly affects the flexibility of the resulting bioplastic. Another parameter that affects the flexibility of bioplastics is the temperature of making bioplastics. Therefore, these two parameters will be studied to compare carrageenan: plasticizer and the optimal temperature for making bioplastics based on tensile strength, the biodegradation rate of bioplastics and degree of solubility in water (Andrey et. Al., 2021; Mona et. al., 2019).

\section{RESEARCH METHODOLOGY}

\section{Equipment and Materials}

This research used materials and equipment as follows:

The materials used were eucheuma cottoni, isopropyl alcohol (IPA), distilled water (aquadest), stearic acid, sodium hydroxide, and sorbitol. The equipment used were a set of extraction equipment and a vacuum oven. The series of extraction equipment can be seen in Figure 2 .

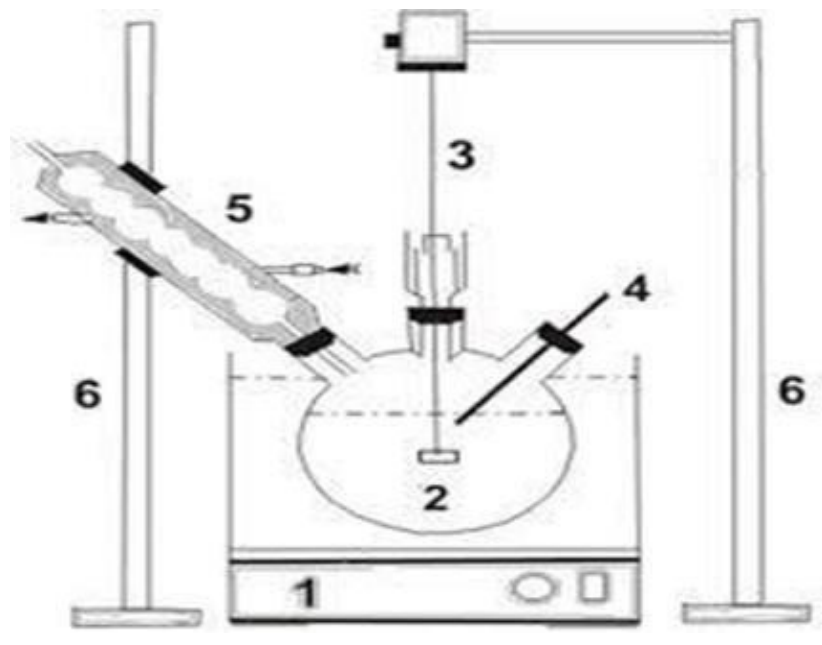

Figure 2. The series of algae extraction equipment: (1) thermostat, (2) three-neck flask, (3) stirring motor,

(4) thermometer, (5) back cooler, (6) static

\section{RESEARCH METHOD}

\section{The Production of Eucheuma cottoni Powder}

The eucheuma cottoni were washed with water until clean, dried and crushed, and then sieved using a 200mesh sieve to produce eucheuma cottoni powder.

\section{Carrageenan Extraction from Eucheuma cottoni}

10 -gram eucheuma cottoni powder was dissolved in 200 -ml distilled water and then put into a threeneck flask for 3 -hour extraction at $60-80^{\circ} \mathrm{C}$. The extract was filtered using a vacuum filter to produce a brownish slurry.

\section{Bioplastic productions}

The algae extract was taken $100 \mathrm{ml}$ and added with 6-ml stearic acid, which had previously been dissolved with isopropyl alcohol and then neutralized using $\mathrm{NaOH}$ until the $\mathrm{pH}$ became 7 (neutral). Then sorbitol was added by $3.5 \%, 4 \%, 4.5 \%$, and $5 \%$. It was then heated at various temperatures ranging $45^{\circ} \mathrm{C}, 50^{\circ} \mathrm{C}, 55^{\circ} \mathrm{C}$, and $60^{\circ} \mathrm{C}$. After that, it was poured into the mould. The bioplastics were formed as a film layer, and then it was dried in an oven for 24 hours at a temperature of $60^{\circ} \mathrm{C}$. The obtained 
bioplastics were then analyzed for tensile strength and elongation, biodegradation rate and water solubility.

\section{Characteristics of Bioplastics}

There are three characteristics of bioplastics to be studied, namely: (1) tensile strength and elongation test,

(2) biodegradation rate, and (3) bioplastic solubility in water.

\section{Tensile Strength and Elongation Test.}

The goals of tensile strength test to determine the resistance of a material to loading at the bending point and examine the elasticity of a material.

Elongation is defined as the percentage change in film length when the film is stretched until it breaks. The tensile strength at break is the maximum tensile strength that can be achieved until the film can survive before the film breaks or tears. The measurement of tensile strength at break helps to know the magnitude of the force committed to achieving maximum tension in each unit area of the film to stretch or elongate. The samples were tested by tensile strength using a Universal Testing Machine brandy Zwick BL-GRS500N.

\section{Biodegradable Rate Analysis}

Laju biodegradasi $=L B=\frac{\left(W_{0}-W_{7}\right)}{W_{0}} \times 100 \%(1)$

$\mathrm{W}_{7}=$ weight of bioplastics after being planted for seven days (gram), $\mathrm{W}_{0}=$ initial weight of bioplastics (gram)

\subsubsection{Water Solubility Analysis}

$$
\text { Daya larut }=D L=\frac{\left(W_{0}-W_{r}\right)}{W_{0}} \times 100 \%
$$

$\mathrm{W}_{\mathrm{r}}=$ Weight of bioplastic after soaking for 10 minutes (gram) and $\mathrm{W}_{0}=$ initial weight of bioplastics

\section{RESULTS AND DISCUSSION}

This research has explained the effects of variations in the sorbitol levels and the temperature of making bioplastics on the physical properties of bioplastics. Sorbitol was used as a plasticizer because it has many reactive $-\mathrm{OH}$ groups in its molecule, making it possible to form higher and more reactive cross-links. The interaction between carrageenan as a polymer and sorbitol as a plasticizer will form cross-links with a chain possibly formed as follows; see Figure 3. 


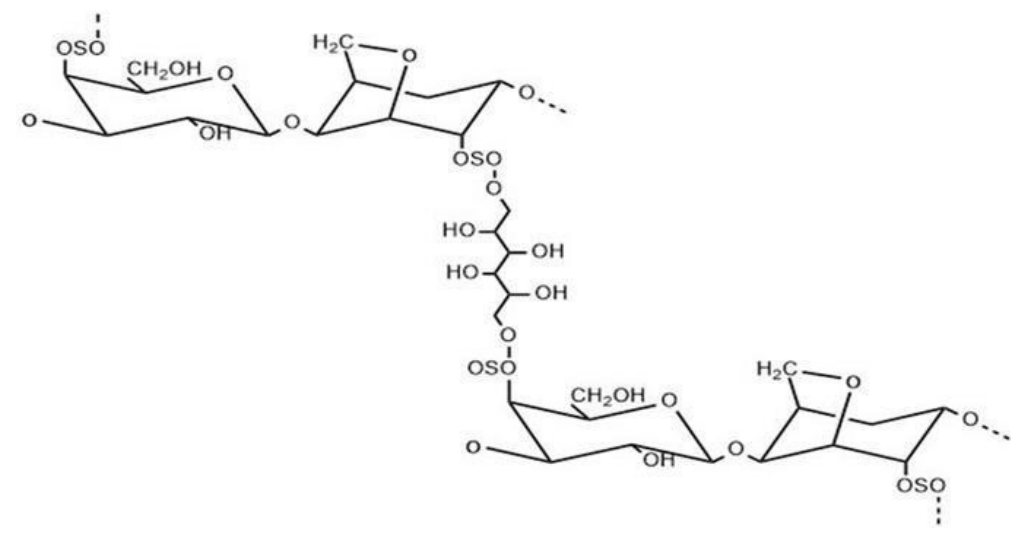

Figure 3. Prediction of the molecular structure of the crosslinked reaction of Carrageenen and Sorbitol

The cross-links formed between the carrageenan and sorbitol molecules cause the flexibility of the bioplastics to be higher. It is not easy to crack; it is plastic. The plasticity and flexibility of the resulting bioplastics are determined by the plasticity content and the temperature of the bioplastic manufacture. The following subchapters will discuss the effects of these two parameters on tensile strength and elongation, biodegradation rate and bioplastics solubility.

\section{Effect of the Temperature in Making Bioplastics on the Bioplastics' Physical Properties}

The effect of temperature on bioplastics' tensile strength, biodegradation, and solubility at sorbitol content remained at $4 \% \mathrm{v} / \mathrm{v}$. Temperature variations performed were $45,50,55$, and $60^{\circ} \mathrm{C}$ with $100-\mathrm{ml}$ extract volume, 2-ml volume of $\mathrm{NaOH}$, and 6-ml volume of Stearic Acid. The tensile strength analysis results can be seen in Table 1. Table 2 shows the effect of temperature on the biodegradation rate of bioplastics.

\begin{tabular}{|c|c|c|}
\hline Temperature $\left({ }^{\circ} \mathrm{C}\right)$ & Tensile Strength (MPa) & Elongation (\%) \\
\hline 45 & 6.8282 & 20.6724 \\
\hline 50 & 6.1054 & 22.5414 \\
\hline 55 & 5.5237 & 22.5631 \\
\hline 60 & 5.1088 & 24.9083 \\
\hline
\end{tabular}

Table 1 shows that the higher of temperature for making bioplastics, the lower the tensile strength. The largest tensile strength was at a temperature of $45^{\circ} \mathrm{C}$, while the elongation was inversely proportional to the tensile strength, following the previous research by Ni Made et. al. (2016). In making bioplastics from tapioca and chitosan at a heating temperature of $70^{\circ} \mathrm{C}$ and a 6-hour heating time, the tensile strength of the bioplastics produced was lower than that of the bioplastics made with a heating temperature of $50^{\circ} \mathrm{C}$. This is becaused the natural polymers are natural materials sensitive to temperature and $\mathrm{pH}$. At high temperatures, there is a possibility that polysaccharides will be hydrolyzed to produce polymers with short chains or oligomers. The hydrolysis of the polymer caused the tensile strength to decrease in Table 1. Following the research results (Ni Made et. al., 2016; Lailatin et. al., 2018) and Table 2, the elongation was inversely proportional to the tensile strength. The effect of bioplastic manufacturing temperature on elongation was that the higher to the elongation temperature, the higher to the elongation (Ni Made et. al., 2016; Lailatin et. al., 2018).

Table 2. Relationship between Temperature and Biodegradation Rate

\begin{tabular}{|c|c|c|c|}
\hline \multirow[b]{2}{*}{ Temperature $\left({ }^{\circ} \mathrm{C}\right)$} & \multicolumn{2}{|c|}{ Bioplastics weight Bioplastics weight } & \multirow{2}{*}{ Mass lost (\%) } \\
\hline & Before (gram) & After (gram) & \\
\hline 45 & 2.1139 & 1.4718 & 30.3751 \\
\hline
\end{tabular}


RSF Conference Series: Engineering and Technology

Vol. 1 (1), 661-668

Bioplastic Productionfrom Eucheuma Cottoni

Mahreni, Yuli Ristianingsih, Asep Saefudin, Affifuroyan Aflah Akmal, Annisa Hindun Narullita

\begin{tabular}{llll}
50 & 2.2611 & 1.3642 & 39.6665 \\
55 & 2.1803 & 1.1745 & 46.1313 \\
60 & 2.3668 & 1.2367 & 47.7480 \\
\hline
\end{tabular}

The biodegradation rate of bioplastics was influenced by the temperature of the manufacture of bioplastics, as shown in Table 2. The higher the temperature, the faster the biodegradation rate. This is because the higher the temperature, the quicker the hydrolysis of the polymer, so that it will increase the number of oligomers as a result of polymer hydrolysis. Microorganisms break down oligomers more quicklythan longchain polymers because microorganisms are easier to use as substrates than break down polymers. Decomposition by microorganisms generally goes through a series of polymer hydrolysis processes by cellulase enzymes produced by microorganisms. The longer the polymer, the more enzymes are needed to break down the polymer. Therefore, in bioplastics made at high temperatures, some polymers have undergone a hydrolysis reaction so that microorganisms decompose bioplastics more quickly.

The homogeneity of the resulting bioplastics can be seen in Figure 4, showing the bioplastics produced at various film-making temperatures. Bioplastics with temperature variations from 45 to $60^{\circ} \mathrm{C}$ can be seen in Figure 4. From Figure 4, it can be concluded that heating at $60^{\circ} \mathrm{C}$ showed the most homogeneous film

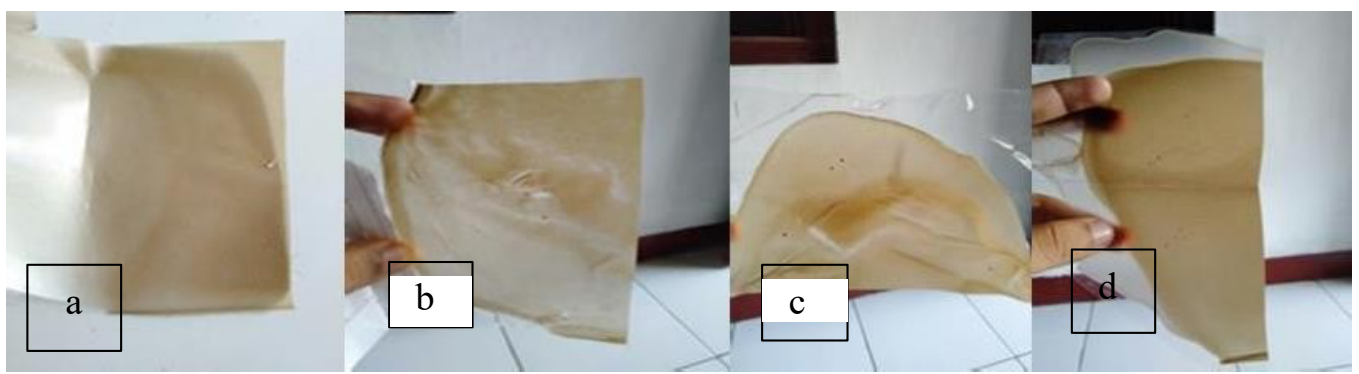

Figure 4. Bioplastics produced from various heating temperatures: (a) $45^{\circ} \mathrm{C}$, (b) $50^{\circ} \mathrm{C}$, (c) $55^{\circ} \mathrm{C}$, and (d) $60^{\circ} \mathrm{C}$.

\section{Effect of sorbitol levels on the physical properties of bioplastics}

The effect of sorbitol levels at a constant heating temperature of $60^{\circ} \mathrm{C}$ on the tensile strength and the degree of biodegradation. The effect of sorbitol levels on the physical properties of bioplastics can be seen in Figures 5 and 6.

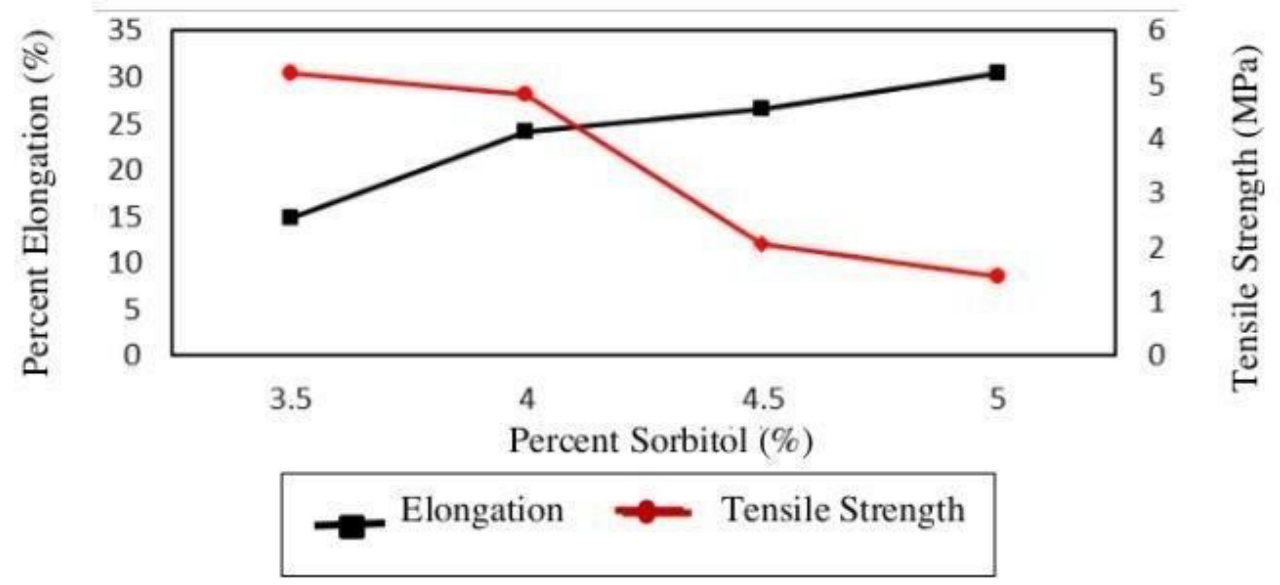

Figure 5. The Effect of Plasticizer Levels on Tensile Strength and Elongation 
The graph in Figure 5 shows that the higher the plasticizer content, the smaller the tensile strength value, andthe greater the elongation. This is because plasticizers can make the distance between molecules wider and produce flexible properties. Plasticizers will reduce the attraction between carrageenan molecules between polymers and encourage bonds between carrageenan molecules and plasticizers. The weakening of the bondsbetween the carrageenan polymers was the cause of the decrease in the tensile strength of the plastic. The increase in levels from 3.5 to $4 \%$ caused the tensile strength to decrease slightly but increased elongation significantly. This study follows previous studies on the manufacture of bioplastics from Cilembu Sweet Potatoes (Lailatin et. al., 2018). Effect of Plasticizer Level on Biodegradation Rate. The biodegradation rate of bioplastics can be seen in Figure 6.

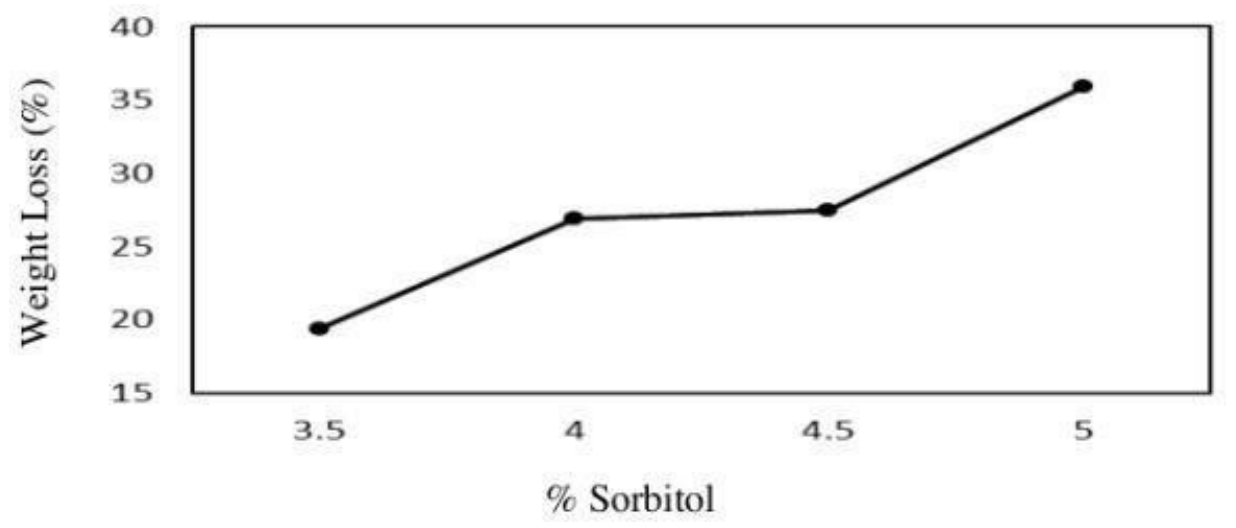

Figure 6. Plasticizer Level on Biodegradation Rate

The graph above shows that the higher the plasticizer content, the greater the percentage loss of bioplastic mass. This is due to sorbitol's nature, which is easily soluble in water, so microbes will easily break it down. In the increase from 3.5 to $4 \%$ and an increase from 4.5 to $5 \%$, an increase in the rate of bioplastic biodegradation was seen, while the increase from 4 to $4.5 \%$ was barely noticeable, so it is could be considered constant.

\section{CONCLUSION}

Based on the data from the analysis of tensile strength and biodegradation rate, it can be concluded that increasing levels of plasticizer could be reduce the tensile strength, and increased the elongation and biodegradation rate. The optimal plasticizer content was $4 \%$, with a tensile strength value of $4.8309 \mathrm{Mpa}$, elongation of $24.1548 \%$, and biodegradation rate of $26.9392 \%$.

The temperature of making bioplastics showed that increasing the temperature could reduce the tensile strength, increased the elongation and the biodegradation rate. The optimal temperature for making bioplastics was $50^{\circ} \mathrm{C}$, with a tensile strength value of $6,1054 \mathrm{Mpa}$, elongation of $22.5414 \%$, and biodegradation rate of $39.6665 \%$, thus it can be concluded that the optimal plasticizer content was $4 \%$, and the optimal bioplastic manufacturing temperature was $50^{\circ} \mathrm{C}$.

\section{Acknowledgement}

This work was supported by LPPM UPN "Veteran" Yogyakarta (Number of contract: B:41/UN.62/PT/IV/2021).

\section{REFERENCES}

Ahmad Z., Yusof, Y., Anuar, H. and Muhaimin, R. M. K. 2012. The effect of Water and Citric Acid onSago Starch Bio-Plastics. International Food Research Journal Vol 19(2). Hal: 715-719.

Andrey A. Tyuftin, Joe P. Kerry. 2021. Gelatin films: Study review of barrier properties and implications for future studies employing biopolymer films. Food Packaging and Shelf Life Vol 29. 100688. https://doi.org/10.1016/j.fpsl.2021.100688.

Aparicio E, Rosa M. Rodríguez-Jasso, C'esar D. Pinales-Marquez, Araceli Loredo-Trevino, Armando 
Robledo-Olivo, Cristobal ' N. Aguilar, Emily T. Kostas, H'ector A. Ruiz. 2021. High-pressure technology for Sargassum spp biomass pretreatment and fractionation in the third generation of bioethanol production. Bioresource Technology. Vol 329. 124935.

https://doi.org/10.1016/j.biortech.2021.124935.

Avérous, L., Pollet, E. eds. 2012. Environmental Silicate Nano Biocomposites, Green Energy and Technology. Biodegradable Polymers, Springer-Verlag, London

Barker, M., Safford, R., Burgner, S., Edwards, C. 2009. Industrial Uses for Crops: Bioplastics URL http://www.hgca.com/publications/documents/Bioplastics_web28409.pdf

Chen X., N. Yan. 2020. A brief overview of renewable plastics. Mater Today Sustainability Vol 7-8. 100031

Chia W. Y., Tang D.Y., Khoo K.S., Lup A.N., Chew K.W. 2020. Nature's Fight Against Plastic Pollution: Algae for Plastic Biodegradation and Bioplastic Production. Environmental Science and Technology Vol 4. Hal: 1-10. https://doi.org/10.1016/j.ese.2020.100065

Daniel Menendez .a, Almudena Alvarez, Paloma Peon, Alba Ardura, Eva Garcia-Vazquez. 2021. Microplastics along the commercial life cycle of red algae. Marine Pollution Bulletin Vol 168. 112402. https://doi.org/10.1016/j.marpolbul.2021.112402.

Dell, K.. 2010. The Promise and Pitfalls of Bioplastic URL http://www.time.com/time/magazine/article/0,9171,1983894,00.html. 3 Mei 2010

Lailatin Nuriyah, Gancang Saroja, M. Ghufron, Arvi Razanata, Nova Fathur Rosid. 2018. Karakteristik Kuat Tarik dan Elongasi Bioplastik Berbahan Pati Ubi Jalar Cilembu dengan Variasi Jenis Pemlastis. NATURAL B Vol. 4 (4). Hal 12-19

Machmud, M. N., Fadi, F., Fuadi, Z., Kokarkin, C. 2013. Alternative Fiber Source from Gracilaria Sp. and Eucheuma Cottonii for Papermaking. In Proceeding of the $7^{\text {th }}$ International Conference of Chemical Engineering on Science and Application. Banda Aceh, Indonesia

Mona Connolly, Yu Zhang, David M. Brown, Natalia Ortuno, Maria Jorda-Beneyto, Vicki Ston, Teresa F. Fernandes, Helinor J. Johnston. 2019. Novel polylactic acid (PLA)-organoclay nanocomposite bio packaging for the cosmetic industry; migration studies and in vitro assessment of the dermal toxicity of migration extracts. Polymer Degradation and Stability Vol 168. 108938.

https://doi.org/10.1016/j.polymdegradstab.2019.108938.

Ni Made Heni Epriyanti, Bambang Admadi Harsojuwono, I Wayan Arnata. Pengaruh suhu dan lama pengeringan terhadap karakteristik Komposit plastik biodegradable dari pati kulit singkong dan Kitosan.Jurnal REKAYASA DAN MANAJEMEN AGROINDUSTRI. Vol 4 (1) , Maret: 21-30.

Sanjaya, I Gede, dan Puspita, Tyas. 2011. Pengaruh Penambahan Khitosan dan Plasticizer Gliserol Pada Karakteristik Plastik Biodegradable dari Pati Limbah Kulit Singkong. Laporan penelitian. FTI ITS, Surabaya.

Stephanis R. De, J. Gimenez, E. Carpinelli, C. Gutierrez-Exposito, A. Ca nadas. 2013. As main meal for sperm whales: plastics debris. Mar. Pollut. Bull Vol 69. Hal: 206-214

Sugih. A. K. 2008. Synthesis and Starch Based Biomaterials. Thesis. Mathematics and Natural Sciences.

University of Groningen

Syed Ali Ashter. 2016. Introduction to Bioplastics Engineering $1^{\text {st }}$ Edition. Plastics Design Library. Hal 1-17. https://doi.org/10.1016/B978-0-323-39396-6.00001-4.

Syed AliAshter. 2016. Commercial Applications of Bioplastics. Design Library. Hal: 227-249. https://doi.org/10.1016/B978-0-323-39396-6.00009-9. 